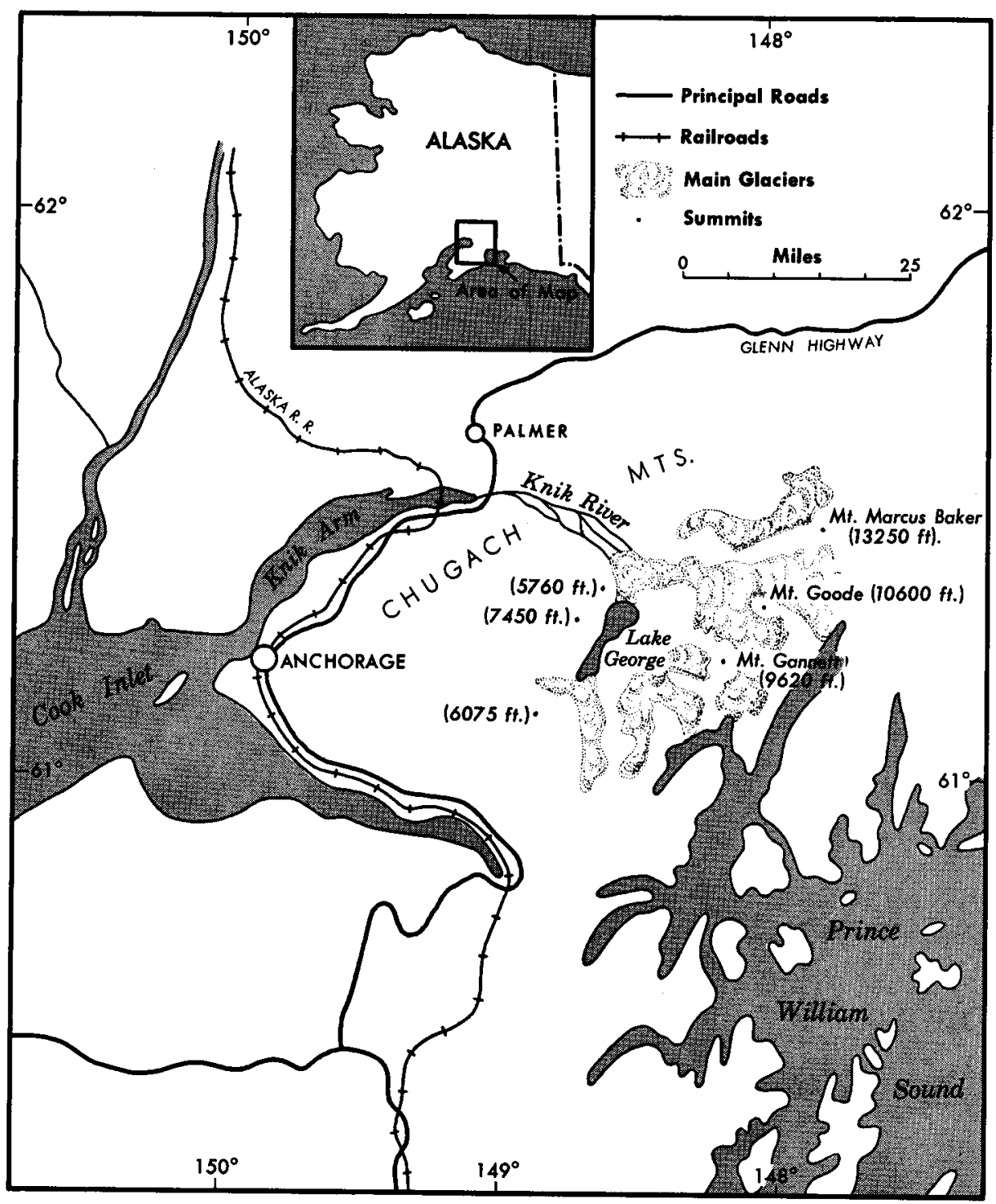

Fig. 1. The Lake George region. 


\title{
THE ANNUAL EMPTYING OF LAKE GEORGE, ALASKA*
}

\author{
Kirk H. Stone†
}

$\mathbf{N}^{2}$

EAR the middle of south-central Alaska lies one of the world's largest ice-dammed lakes. This is Lake George, of interest to many because it empties naturally each year. Such a phenomenon has led to speculation about its cause and for decades has attracted attention on account of the resulting floods that often are destructive. Yet, by 1951 the characteristics of the lake were still little known and observations were begun to procure data for analytical studies. Lake George was found to be a hatchet-shaped body of water that filled in early summer to become about 2 to 4 miles wide, 11 to 12 miles long, and 114 feet deep. In 12 days during mid-summer this became three small and shallow lakes. It is intended that the description and partial interpretation of the emptying will provide a basis for further research on the process and on the glaciological history of the lake basin.

\section{Regional and site characteristics}

Lake George is situated on the northern side of the Chugach Mountains of south-central Alaska, about 45 miles east of Anchorage (Fig. 1). When emptying the water flows into the southeastern corner of the Matanuska Valley, south of the city of Palmer, where the floods require special protective measures at the bridges of the Alaskan highway and railroad systems.

The lake occupies a valley that extends to the southwest from the western end of Knik Glacier. The northwestern corner of the lowland is about 230 feet above sea-level and the walls of its valley on the eastern and western sides are a slate-like bedrock with slopes of 20 to 30 degrees

* Principal support for this study was provided through contract between the O.N.R., Department of the Navy and the Arctic Institute of North America. Reproduction in whole or in part is permitted for any purpose of the United States Government.

$\dagger$ Department of Geography, University of Wisconsin. 
that culminate in sharp peaks between 5500 and 7500 feet high (Fig. 2). A thick growth of alder, willow, and aspen covers most of these slopes to altitudes of about 1000 feet; above these grass and moss are found to about 1500 feet.

Jutting across the north end of the Lake George valley is Knik Glacier. It arises in the mountains about 15 miles east of the lake (Fig. 1) at altitudes of roughly 8000 feet and flows generally westward in a steep-sided valley that is about 3 miles wide at the glacier terminus. Where the valleys of Lake George and Knik Glacier meet the latter makes a sharp 45-degree bend to the northwest. There the ice mass jams into the mountains at the turn and part of it flows southward into the northern end of the Lake George basin. The lake is south of this ice and it is between the ice and the mountains that the temporary outlet of the lake is formed each summer.

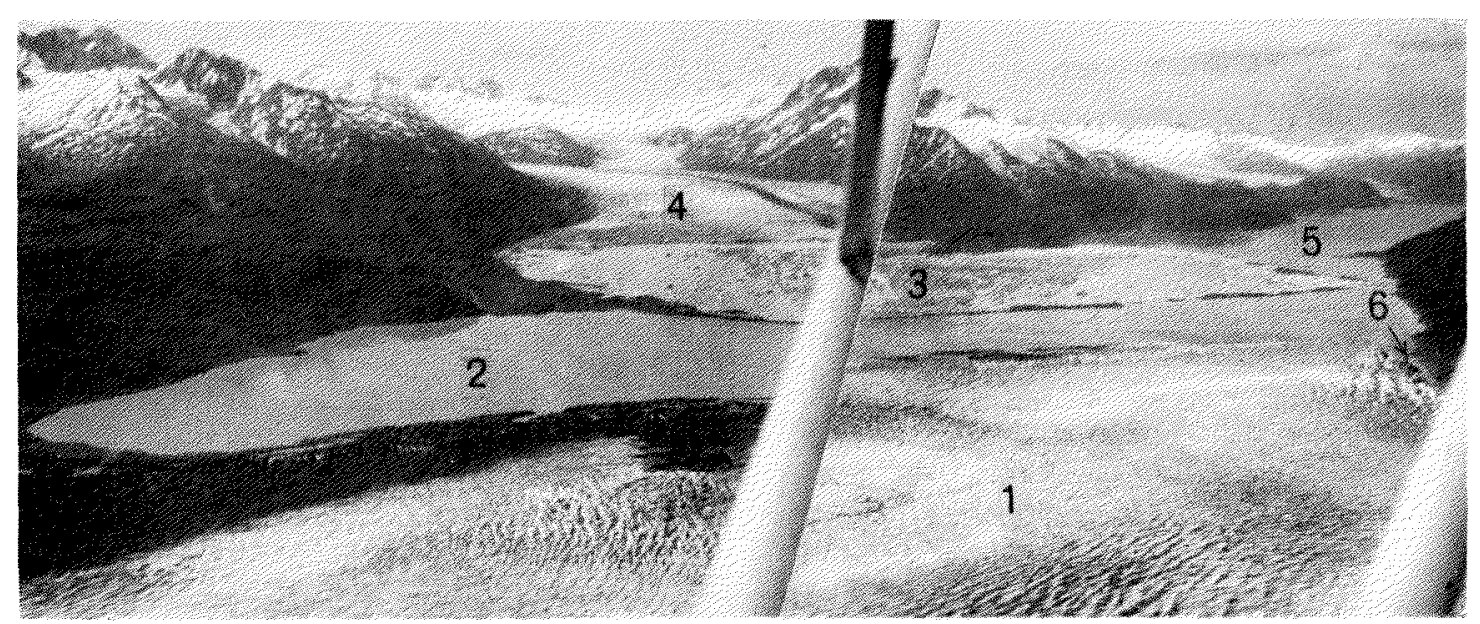

F'1g. 2. View south over Lake George. (1) Knik Glacier, (2) Lower Lake, (3) Inner Lake, (4) Colony Glacier, (5) Upper Lake, (6) beginning of the Gorge; July 3, 1951.

\section{Previous mapping}

A map of 1880 (U.S. Dept. of the Int. 1884, plate 1) was the first to show Lake George. It was mapped as about 15 by 12 miles and north of its true position. This was repeated on other maps (Allen 1900, map I; U.S. Coast and Geodetic Surv. 1887) until 1898 when the lake was shown to be about 2.5 by 6 miles and oriented east-west (Glenn and Abercrombie 1899, map 1). It is likely that these early records of the lake were not based on close field observations for there was no known exploration of or traffic through the area (Stone 1950, pp. 3-6; 1952).

However, a map based on field work in 1906 introduced reliability (Paige and Knopf 1907, plate 1). It showed correctly the size, orientation, and location of what is at present the southern part of Lake George after emptying. 
However, it was not until 1943 that the lake was shown almost correctly at its full stage (U.S. War Dept. 1943). Even then great accuracy could not be obtained from different sets of oblique aerial photographs that showed five different shapes and levels of Lake George. These differences still hamper mapping today.

\section{Lake George in 1951}

Knowledge of the annual changes of such a lake is basic to the analyses needed. The year 1951 is the first for which some data are available. Furthermore, the variations in 1951 are representative of most years since 1939 .

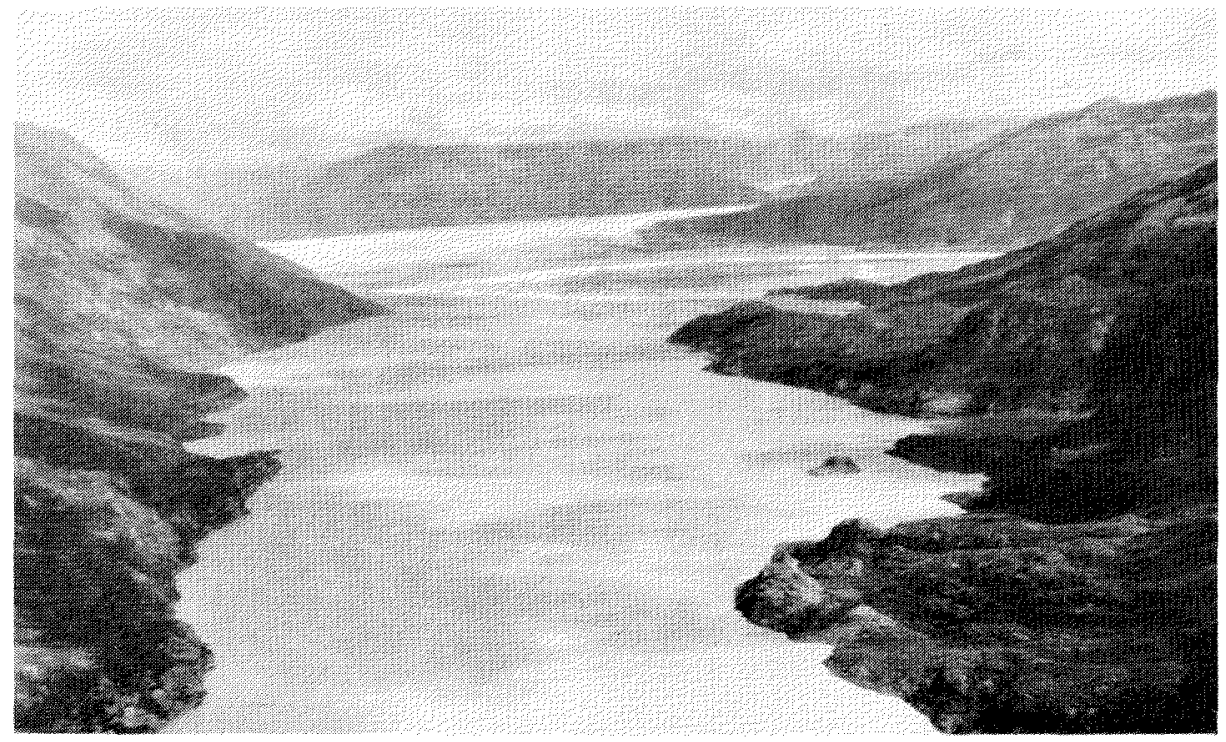

Fig. 3. View north over Lake George from about 3300 feet above the southern shore line. The lake was at its highest stage and began to empty on this day; July 20, 1951.

In June 1951 Lake George was solidly dammed. Knik Glacier extended across the 4 miles of the north end of the lake basin and at that point was about 7 miles wide. It had rammed against about 5 miles of the base of the mountains at the northwestern corner of the lake.

In detail the damming was at points. There were five and each had a small moat-like lake on its southern side. Westward of each point the slopes of the slate-like rock were vertical and bare, or very steep with a nearly continuous cover of willow and alder about 4 feet high. On the other side were vertical faces of ice about 300 feet high; the principal crevasses roughly paralleled the ice-rock contact line.

In 1951 the lake reached its maximum size on July 20. It was then shaped like a hatchet with the blade at the northern end (Fig. 3). This was about 4 miles wide east-west and 3.5 miles long north-south, the "handle" 
part extending another 7 miles to the south and being nearly 2 miles wide. The water level was about 342 feet above sea-level, as determined from altimeter readings, controlled at the Palmer airport, and the depth was 114 feet in the northwestern corner. There were five small islands in the lake and a great concentration of icebergs in its northern part.

In 12 days the lake emptied. Signs of the beginning were first seen near the northwestern corner where an east-west line of scum on the lake rotated through $90^{\circ}$ until it was parallel with the axis of the outlet and then moved into the corner of the lake. In the following 12 days the lake level dropped 114 feet (Fig. 4). In the first 48 hours, until the afternoon of the 22 nd, it fell only 2 feet; by that time the hourly rate was only 1 inch. The main change took place during the 8 days after the 22nd when the lake level dropped 110 feet to the 232-foot level. The rate of fall accelerated from about 2 to 4 inches per hour on the 23rd to nearly 12 inches per hour on the 29th (Fig. 5). On the 30th the rate of fall decreased rapidly; the main body of water had run out.

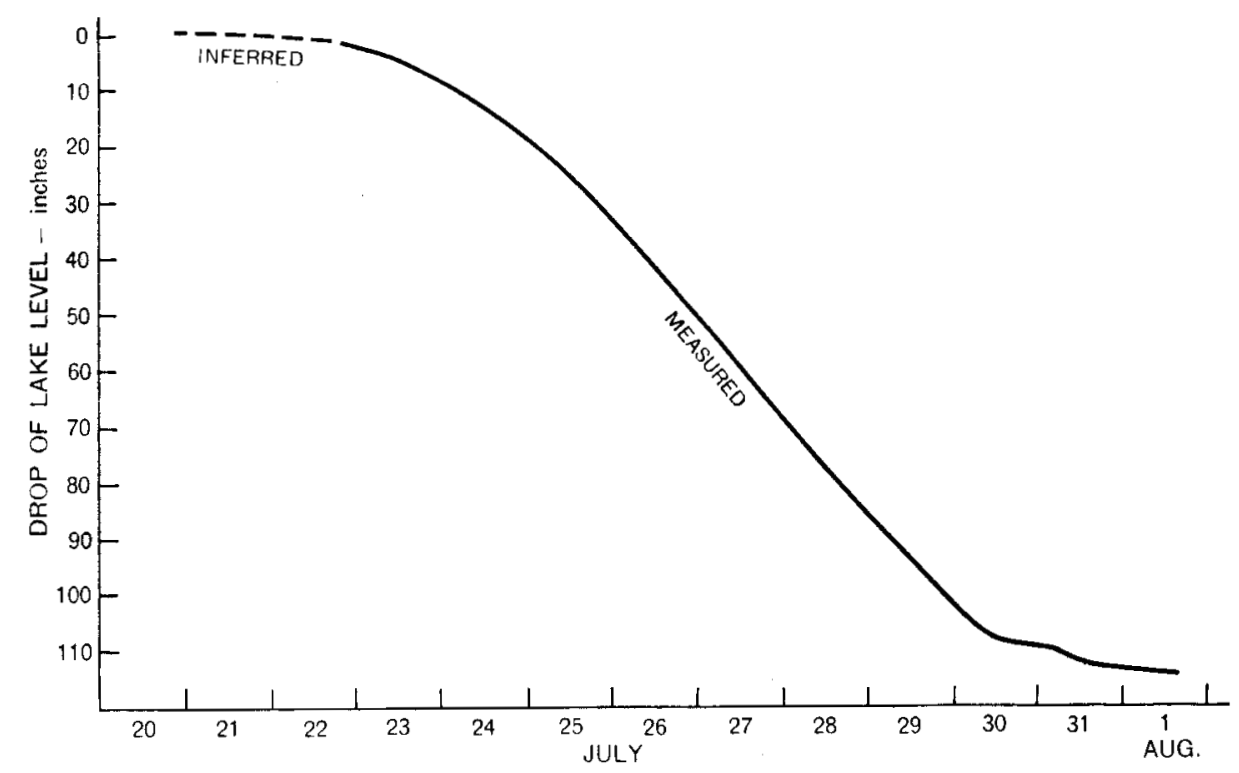

Fig. 4. Lake George, change of level of lake while emptying, 1951.

The drop of the lake level was accompanied by flooding in the Knik River valley. At the Palmer highway bridge a slow-moving stream roughly 150 feet wide changed to a fast-moving river nearly 4000 feet wide. At noon of the 20th, when the lake began to empty, the river was 7 feet deep in the main channel. In the following 7 days the river rose steadily until it was nearly 20 feet deep, after which it fell in 4 days back to 10 feet (Fig. 6). These fluctuations in depth were accompanied by great changes in discharge, from less than 20,000 second-feet on the 20th to about 182,000 on the 27 th 
and back to about 20,000 second-feet by August 2nd, as measured by personnel of the U.S. Geological Survey.

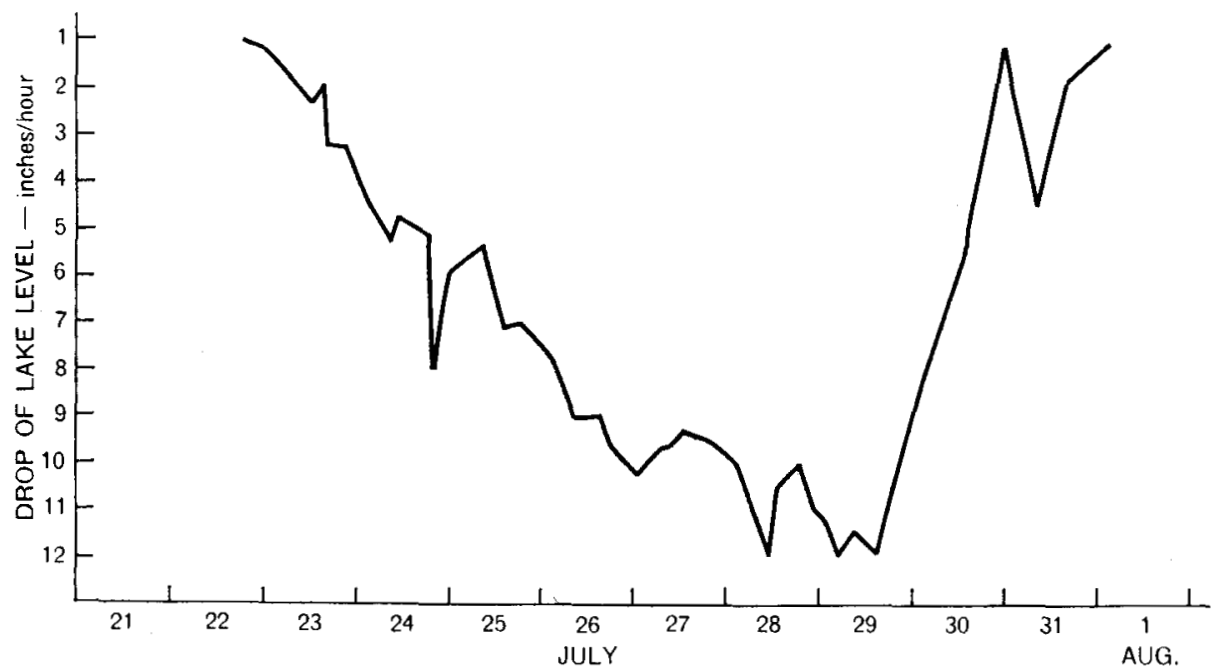

Fig. 5. Lake George, hourly rate of fall of level of lake, while emptying, 1951.

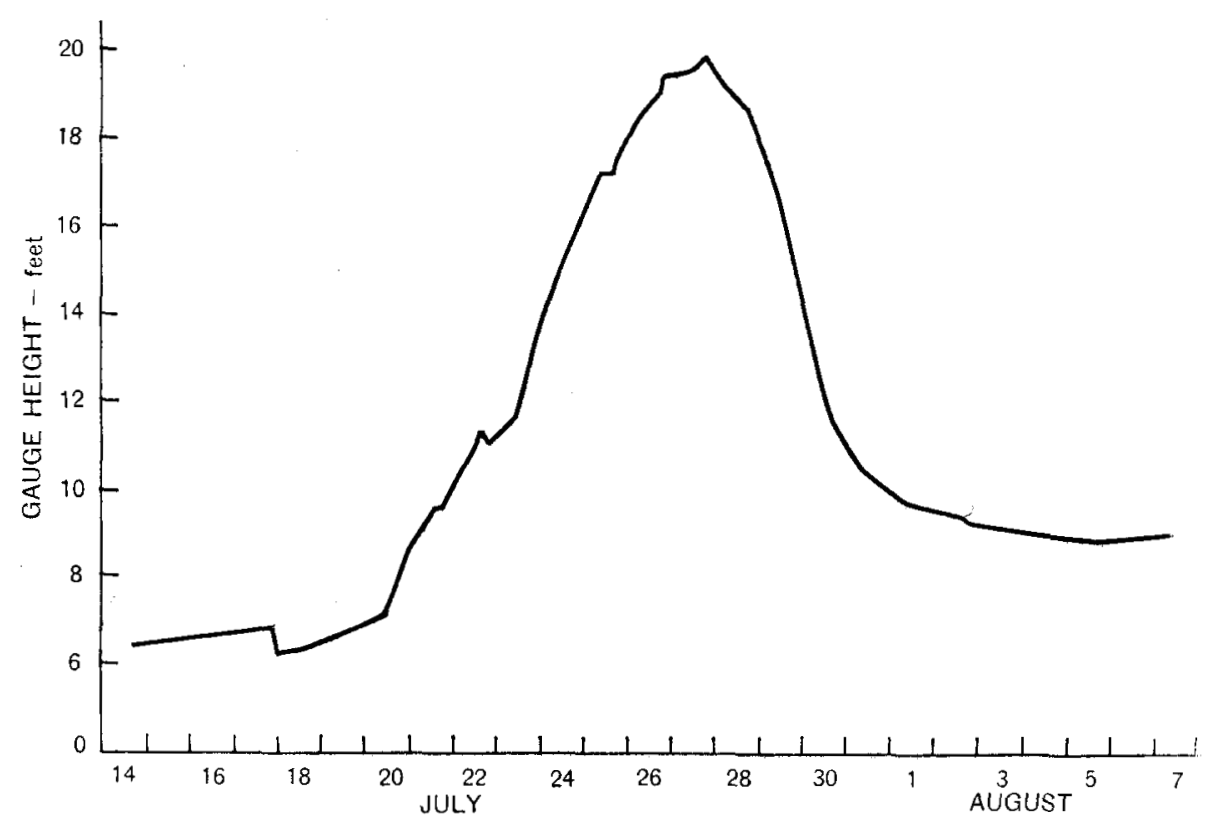

Fig. 6. Knik River, gauge heights of river during emptying of Lake George, 1951. (Data in part from U.S. Geological Survey.)

The outlet channel, here called the Gorge, was formed in about 4 days. It was made by water flowing under the ice past the five dam points; at no 
time or point did water go over a dam (nor is there any evidence that this ever happened). During the first 2 days there was no continuous open channel, but between late on the 22nd and the 24 th the dams collapsed. Then the Gorge was opened by undercutting and flushing out. Masses of ice between 100 and 250 yards long, 50 to 150 feet thick, and 200 to 300 feet high toppled over (Fig. 7). Channel cutting accelerated until the 25th when the Gorge was a 100 - to 300-foot-wide, 300-foot-deep, and 5-mile long trough between the Knik Glacier and the mountain.

Development of the Gorge probably depends on complex relationships between several local and regional elements. To be considered are: amount and temperature of the water at the head of the Gorge (where it averaged $37^{\circ} \mathrm{F}$. during the opening), strength of Knik Glacier at the damming points, climatic characteristics of the region, weather in the basin before and during emptying, solar heating of the rock on the west side of the Gorge, and pos-

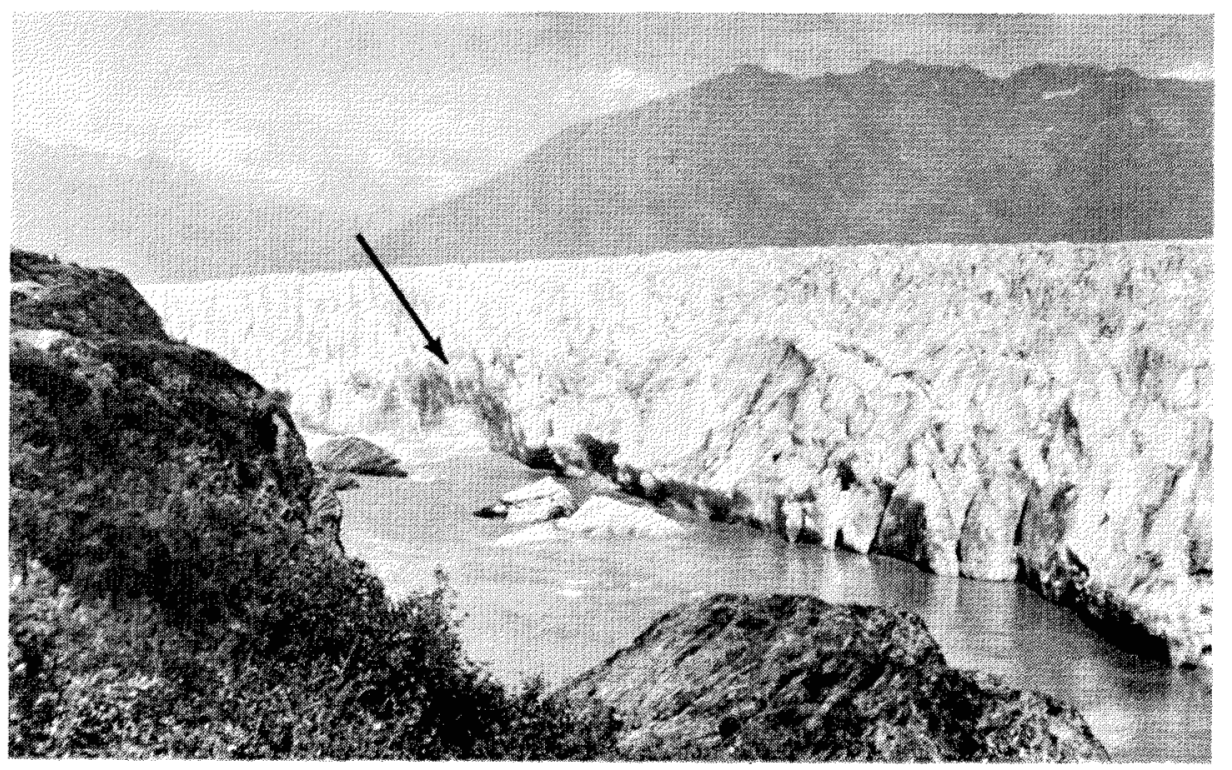

Fig. 7. View northeast across the Gorge, about 1.5 miles from Lake George. At the arrow the height of the ice was about 300 feet; a large section had just fallen. Other pieces of ice in lower centre are being flushed downstream (to left); July 25, 1951.

sibly earthquakes. Some of these elements are unknown, but an analysis of climatic and weather data from the nearest stations showed no significant correlations.

After emptying the Lake George basin included three lakes with 42 per cent less water surface (Fig. 8). Of the three, Lower Lake was the most northerly, the smallest and the lowest. It had an average depth of 4 to 8 feet and a maximum of 21 feet in the middle of its eastern half. The lake emptied through a winding stream that gradually descended 7 feet in its westward course. 


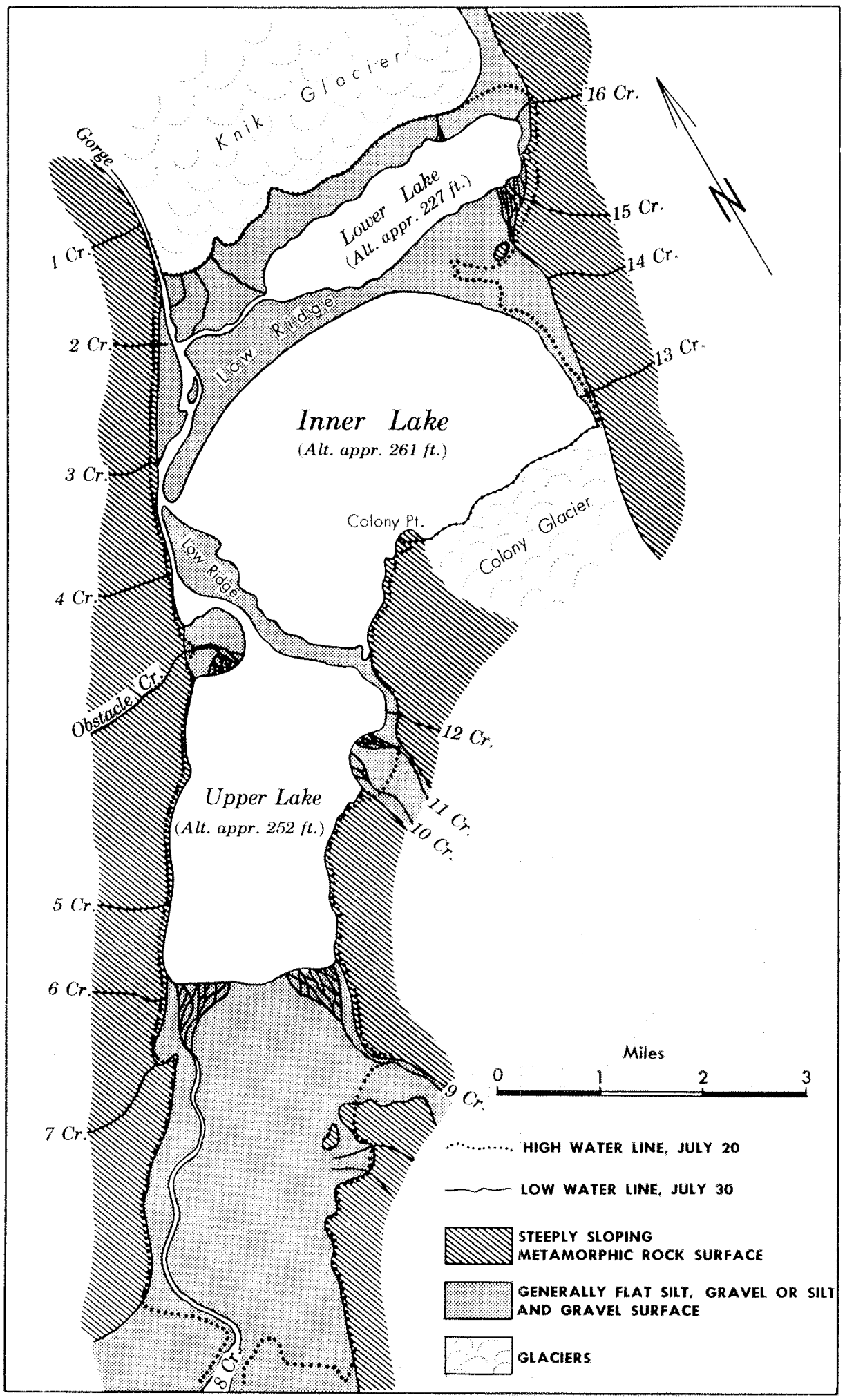

Fig. 8. The Lake George basin when empty on July 30, 1951. 
Inner Lake was the highest and, with an area of about 8 square miles, the largest. Low Ridge bounded most of it with an average height of 100 feet above the lake level; the outlet through the ridge was only 2 feet deep, 30 feet wide, and on gravel. Into the lake flowed Colony Glacier (named Surprise Glacier on some maps) with a sheer ice face 150 to 250 feet high; ice calving from it, especially during emptying, filled the lake with bergs that prevented measuring its depth.

Upper Lake was the most southerly and between the other two in altitude of water level and in size. However, the mapped position of its southern end may be inaccurate because of gradually shallowing water there. Elsewhere average water depths were 16 to 20 feet, even close to the steeply sloping eastern and western sides. The sill that controlled the level of the lake was in the 500-foot-wide outlet off the northeastern corner of Obstacle Creek delta.

In addition to these lakes there were two flat land areas in the basin. The bigger was on the south, where a silt-filled depression about 2 miles wide extended 6 miles southward from Upper Lake; nearly 4 miles of this was submerged at the time of high water. In the northern part of the basin were narrow strips of silt adjoining Lower Lake and of gravel next to Low Ridge and the northwestern slopes.

Lake George was dammed again during the winter of 1951-2. As the water in the Gorge decreased it could no longer undercut the continually advancing ice. Pilot L. M. Green observed: in November that the width of the outlet was reduced about one-quarter and in some places ice had fallen across the Gorge; in January that the stream was frozen and closure appeared to be complete (under snow) at several points; and in April that several dams were fully formed. Thus was completed a cycle that had occurred in many previous years and is still occurring annually.

\section{Other emptyings}

First knowledge of Lake George is based on reports of destructive flooding. Mendenhall (U.S. Geological Survey 1899, p. 298) noted that just prior to 1900 a great flood from the Knik River valley destroyed three Indian villages near the head of Knik Arm. Admiral Patton (1914, pp. 8-9) reported that after a great flood in Knik Arm the village of Knik could be reached only by small craft at high tide and that local Indians described a lake that emptied into the Knik River with terrific force about once every 15 or 20 years.

Since 1918, at least, Lake George has emptied annually. In that year the Alaska Railroad bridged the mouths of the Knik River and every year since special protective measures have been necessary. At the highway bridge built in 1935 crews also have been present every year to prevent damage during flooding.

Since 1935 the annual emptyings have been starting earlier. The change has been about a month from approximately August 20 in the 1930's to July 
15 at present (Fig. 9). The maximum variation has been 68 days between early September 1937 and late June 1959. However, variations between consecutive years since 1935 have usually been less than 20 days and in 16 periods less than 10 days. There is thus a clear trend toward starting to empty earlier each year.

Furthermore, since 1949 earlier emptying has been accompanied by more flooding in the Knik River (Fig. 9). In that time maximum flood heights at the Palmer Highway bridge have varied from 19 to 20 feet in the first 4 years to 24 to 25 feet in the next 5; the exception was the small flood associated with the earliest recorded emptying in 1959.

The record of flooding in $\mathbf{1 9 5 1}$ at the bridge was representative of the usual sequence there. Graphs of flood stages in 1955, 1956, and 1957 have the same curves but different maxima. Those for 1954, 1958, and 1959 show faster rises, shorter crest periods, and shorter post-crest periods. This was especially true in 1958 when the river reached in only 4 days the highest flood stage ever recorded (a 25.3-foot crest and 359,000 second-feet maximum discharge, as measured by personnel of the U.S. Geological Survey) and dropped to less than 15 feet in the following 2 days.

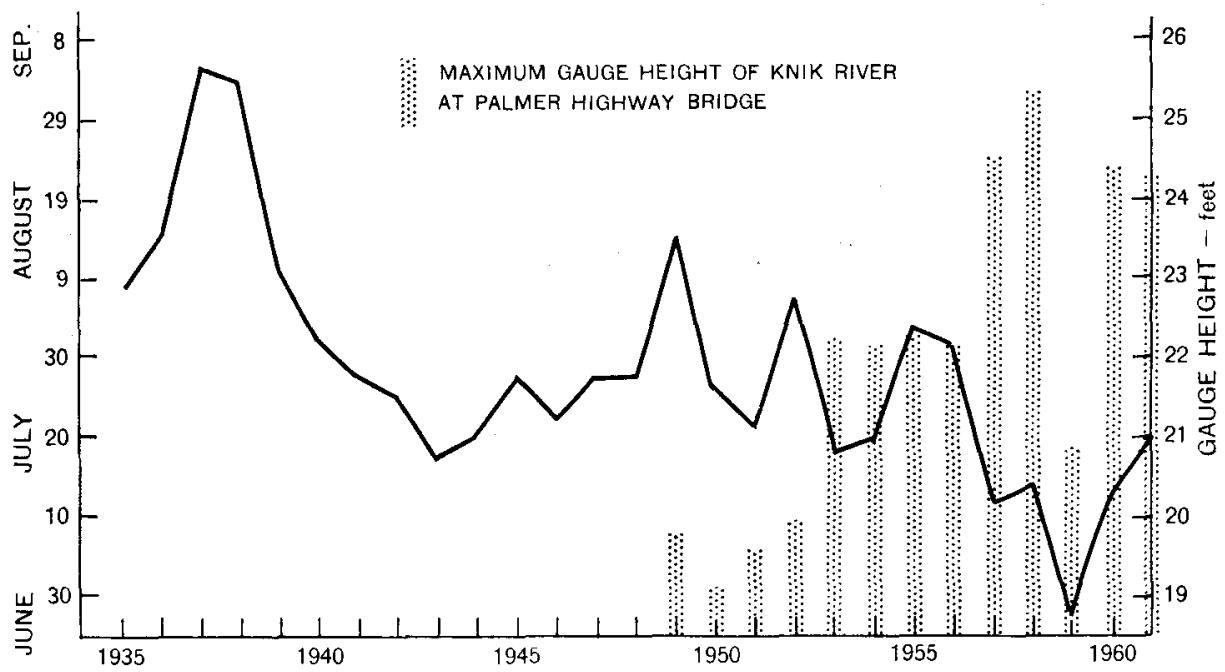

Fig. 9. Lake George, dates of start of annual emptying and maximum gauge heights of Knik River at Palmer highway bridge. (Data in part from Alaska Railroad, Alaska Road Commission, and U.S. Geological Survey.)

Relationships between these floods and the volume of Lake George are uncertain on account of lack of data. Lawrence's computations (1949) were the first to suggest the degree of difference in the size of the lake from year to year. In 1951 it was determined from plant materials in lines of debris near 11 Creek that Lake George had a maximum altitude in that year that was less than those of at least 4 previous years (Fig. 10). The probable highwater level in 1950 was 51 inches above the maximum of 1951. A line for 
1949 was missing. However, 18 inches above the 1950 mark was the possible level for 1948 and another 8 inches higher was the possible level from 1947. Lake George thus appeared to have been 6.5 feet deeper in 1947 than in 1951 but relations, if any, between the volume of the lake, the start of emptying, and the stages of flooding in these years are unknown.

\section{Age of the lake}

One of the more fascinating and significant topics of study in the area is the determination of the ages of the three parts of Lake George. At least three lines of inquiry are possible.

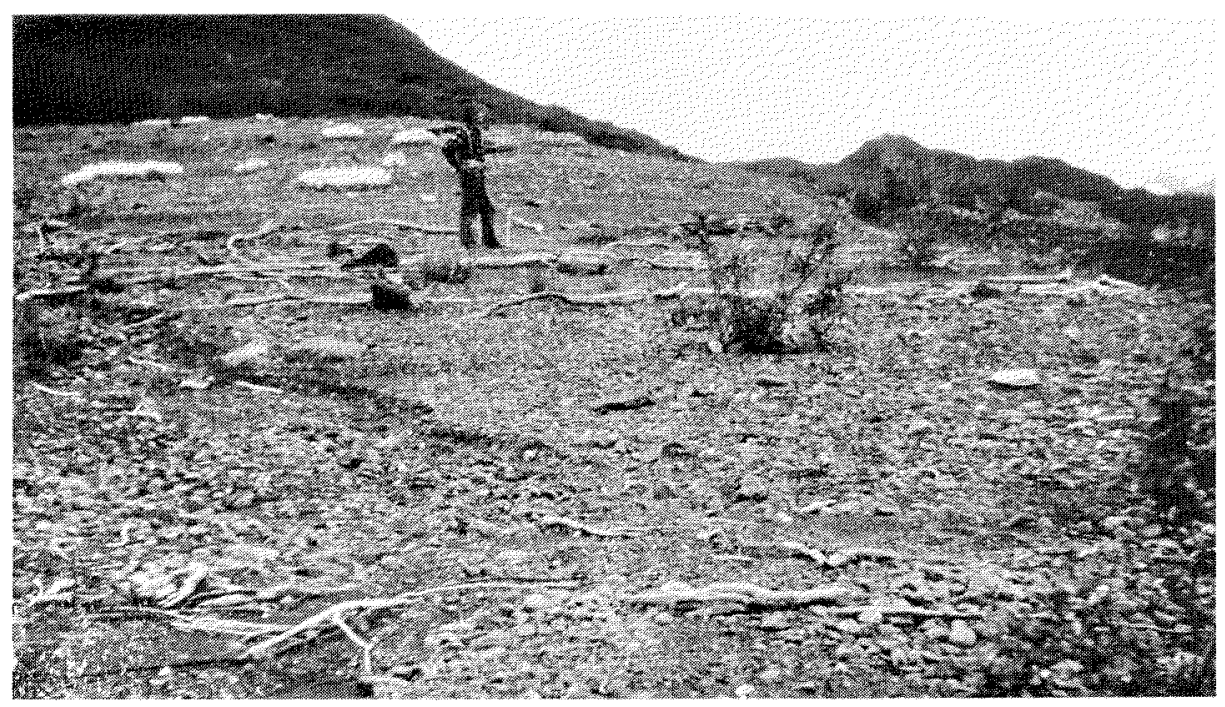

Fig. 10. Upper northern part of delta of 11 Creek with high-water marks. Lowest is that of 1951, the next higher possibly that of 1950, followed by those of possibly 1948 and 1947; August 7, 1951.

The first concerns the terracettes. These "steps" on the edges of the basin have been found throughout the area. They are best developed between the low-water level of 1951 and one 150 feet higher but on some slopes they occur a further 100 feet higher, well above the high-water level of 1951. They are formed in silt, sand, gravel, and coarse talus, occur as 30 to 40 consecutive units, vary from 2 to 12 inches wide and 2 to 12 inches apart vertically, and they are horizontal and tilted slightly toward the lake (Fig. 11). On the southwestern side of Colony Point are found several tens of terracettes whose flat parts continue as stain lines across the face of an adjacent cliff (Fig. 12).

The higher and lower terracettes have different distributional patterns. The former occur on both sides of Upper Lake and on the eastern sides of Inner and Lower lakes. However, there are none in the vicinity of 2 and 3 Creeks, possibly because the surface there is bedrock and boulders. The 
lower terracettes, particularly those below the high-water line of 1951, are widely distributed. They are well developed near the deltas of Obstacle Creek and 14 Creek, as well as on both sides of Low Ridge. They are equally well developed in exposed and in sheltered localities; in particular the lower terracettes on the moraine next to Knik Glacier are well developed even though waves 3 to 4 feet high broke over them for 2 days in 1951 .

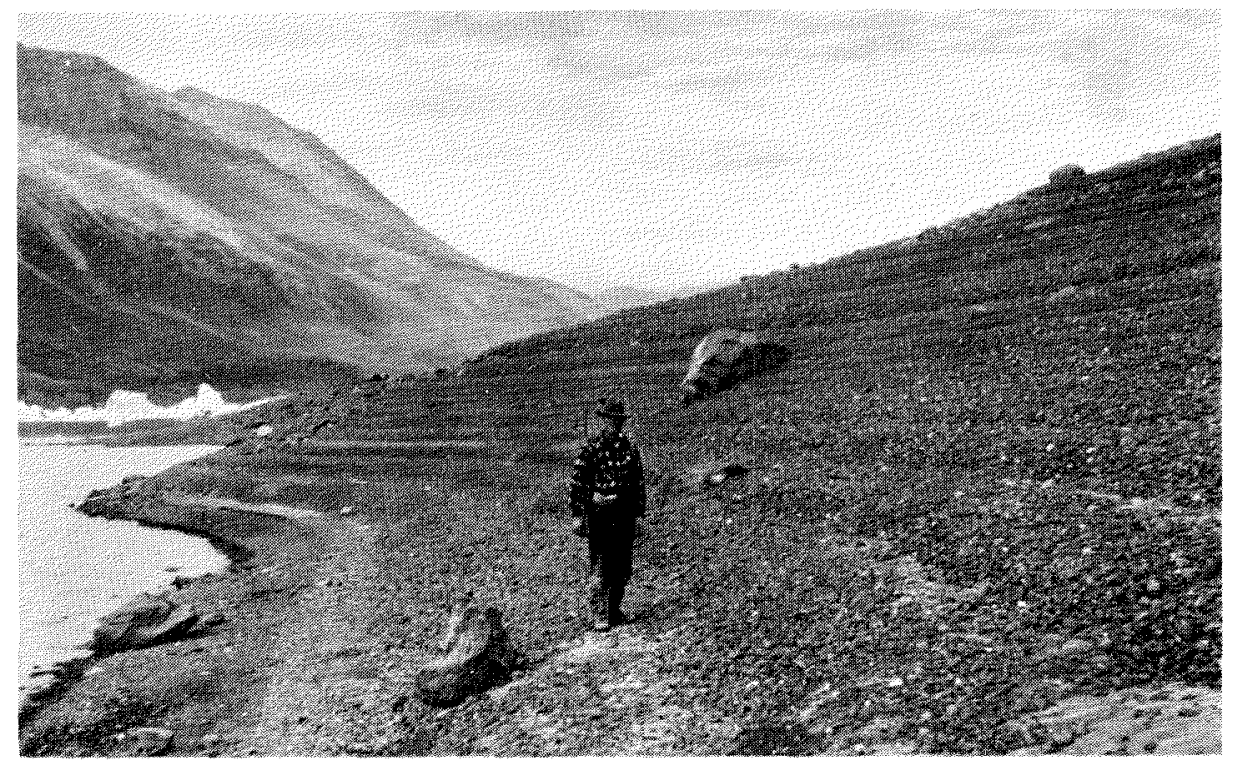

Fig. 11. View (looking northeast) of terracettes at the northeastern corner of Upper Lake. The person was standing on the second of more than 20 of the larger terracettes formed in loose gravel between the low-water line and the top of this southern part of Low Ridge; August 7, 1951.

One of the questions remaining is how long it took to form a terracette. The suggestion of short stagnations at high water and during emptying or filling appear unacceptable. The maximum level is maintained for probably less than a day and temporary levels at other times for even shorter periods. The theory of formation by drainage in a moat between an ice-covered lake and a frozen or thawed shore would require a lake that does not empty and would result in terracettes sloping toward the Gorge; in fact the lake emptied annually in recent decades and the terracettes are horizontal. The idea of a water level being stationary for a considerable length of time is possibly supported by the stain lines, as well as by the firmness of the terracettes in many localities. An additional hypothesis is that these micro-landforms originated during long periods of time when the lake emptied only once in 15 or 20 years.

A second possibility of determining the age of the lake might be the dating of the willows and alders nearby. Observations in 1951 along a line between 1 and 2 Creeks indicated that above the altitudes of about 500 feet 
above sea-level the willows were about the same size: 5 inches BHD and approximately 10 to 12 feet high. Several of these were found to be 22 years old. At about 465 feet above sea-level only the oldest trees averaged 22 years and at about 387 feet (about 45 feet above the 1951 high) the ages averaged about 17 to 20 years. Near the high-water line of 1951 willows were also 17 to 20 years old; however, one specimen, which was about 5 feet high and 9 years old, was partly submerged in 1951 and a still smaller tree that was completely under water in 1951 was approximately 5 years old then. The significance of this dating, especially where the terracettes extend upward into the areas of bushes and trees, is still unknown.

The third line of inquiry concerns the size of several deltas in the basin. The biggest, that of Obstacle Creek, is at least 156 feet thick at its head. Its upper half is composed of coarse gravels in steep slopes, whereas the remainder consists of silts and finer gravels in very low slopes cut by distributaries (all flowing southward, rather than northward in 1951). The delta measured more than 0.5 mile in either direction at low water (Fig. 8). Such a mass deposited by so small a stream probably took several years to accumulate.

There are at least three other exposed deltas. Two are on the western side at the mouths of 2 and 3 Creeks and one on the eastern side at the mouth of 14 Creek. The tops of the western deltas are at altitudes of about 405 feet, or about 63 feet above the high-water mark of 1951 and both are smaller and more poorly defined than that of Obstacle Creek. The delta of 14 Creek has its head in a similarly indented site but its maximum altitude is about 100 feet higher than those on the western side. Furthermore, the eastern delta is much more extensive than the other two and is cut by a steep-sided and narrow channel.

Probably there are other means of dating. Determination of the directness of the apparent relationship between Low Ridge and Colony Glacier might aid determination of the age of at least Inner Lake. Perhaps there are varves below the bottoms of the three lakes; attempts were made to procure them from Lower and Upper Lake, but none were found, which may have been because of inadequate equipment.

\section{Research potential}

Additional study in the Lake George basin is likely to provide significant data. One type concerns detailed glaciological activity in the basin and region and other information could be used to reduce losses by flooding. Among the more important subjects are: forecasting of the emptying date and severity of flooding, variations in the process of formation of the Gorge, determination of pre-1935 emptying dates, the causes of variation in the dates of the beginning of emptying, differences in the speed of emptying, previous sizes and volumes of Lake George, and historic and recent glacial movements in the basin. 
Research on several of these topics will be necessary to obtain a clear glaciological understanding of Lake George. This is needed not only for that area but because there are 52 other ice-dammed lakes in Alaska and adjoining Canada and it is probable that there are geographical and glaciological characteristics that are common to most of them.

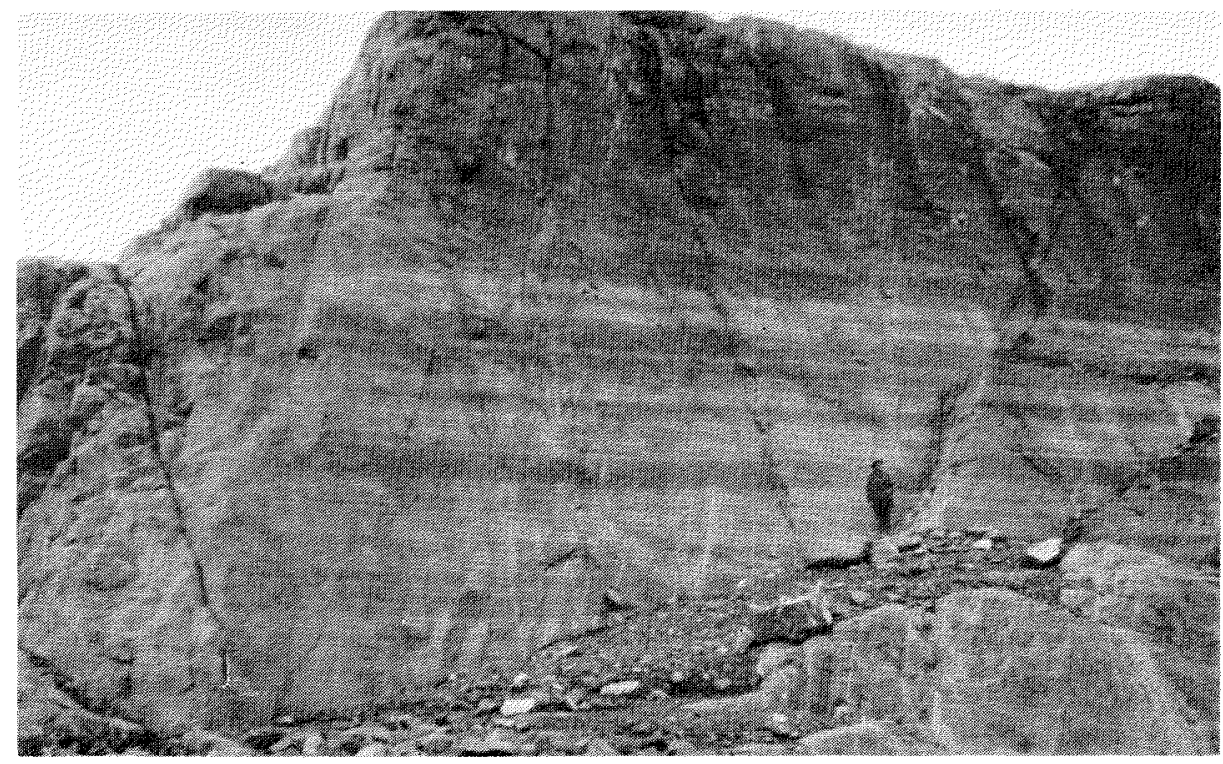

Fig. 12. View of stain lines in slate-type rock about 200 yards inland and southwest of Colony Point, on the southern shore of Inner Lake. The more sharply defined lines continued beyond the right edge as terracettes in fine gravel. All were below the highwater level of 1951; August 4, 1951.

\section{Acknowledgements}

In addition to the support from ONR, this study was aided by the University Research Committee and the Whitbeck Faculty Research Fund in Geography at the University of Wisconsin. Many other agencies and persons contributed in various ways. Especial aid in the field was given by pilot L. M. Green, guide J. D. Richardson, and geologist M. J. Slaughter, all of Palmer, and in Madison by W. F. Thompson, Jr. First observations were made in 1941,1946 , and 1948, the principal field work was done in the summer of 1951, and an additional aerial reconnaissance of Lake George was made in early January 1959. 


\section{References}

Allen, Lt. H. T. 1900. Report of military reconnaissance in Alaska in 1885. In (U.S.) Senate Comm. on Milit. Aff., Compilation of narratives of explorations in Alaska. Washington, D.C., pp. 409-88.

Glenn, Capt. E. F., and Capt. W. R. Abercrombie. 1899. Reports of explorations in the territory of Alaska, 1898. War Dept. Adjut. Gen. Office, Mil. Inform. Divis. Publ. No. 25, War Dept. Doc. No. 102, Washington, D.C., 464 pp.

Lawrence, F. F. 1949. Knik River flood of July-August 1948. U.S. Geol. Surv., Portland, Oregon. (mimeo.), $4 \mathrm{pp}$.

Paige, S., and A. Knopf. 1907. Geologic reconnaissance in the Matanuska and Talkeetna basins, Alaska. U.S. Geol. Surv. Bull. No. 327, Washington, D.C., 71 pp.

Patton, R. S. 1914. Descriptive report of 1914 accompanying hydrographic survey No. 3674, Knik Arm, Cook Inlet, Alaska. U.S. Coast and Geodet. Surv., Washington, D.C., pp. 7-9.

Stone, K. H. 1950. Alaskan group settlement, the Matanuska Valley colony. U.S. Dept. Int., Washington, D.C., 95 pp. 1952. Some geographic bases for planning new Alaskan settlement. In Science in Alaska. Washington: Arctic Institute of N. Am., pp. 136-50.

U.S. Coast and Geodetic Survey. 1887. Alaska, map No. 960, 1:3,000,000. Washington, D.C.

U.S. Dept. of the Interior, Census Office. 1884. Tenth census of the U.S., 1880. Washington, D.C. Part 8, 189 pp.

U.S. Geological Survey. 1899. Twentieth annual report, part 7: explorations in Alaska, 1898, Washington, D.C., 509 pp.

U.S. War Dept., Corps of Engineers. 1943. Metal Creek quadrangle and Surprise Glacier quadrangle, 1:62,500. Portland, Oregon. 